\title{
Enteroviral infections in cases of miscarriage
}

\author{
Eman A. Mohamed - Daad F.I. El Fouhil - Soad E. Abdel Rehim \\ Jaylan A. Ali - Salwa E. Abdel Hamid
}

\author{
Microbiology Department, Faculty of Medicine for Girls, Al-Azhar University
}

\begin{abstract}
To investigate enteroviral infections as possible causes of miscarriage in pregnant women, 100 women with miscarriage were studied, 75 of whom had miscarriage before the $13^{\text {th }}$ week of gestation (group A) and 25 had miscarriage after the $13^{\text {th }}$ week of gestation (group B). Placental tissue samples were taken from all women and were investigated for the presence of enteroviruses by cell culture in Vero cell line. The viral isolates of cell culture positive samples were subjected to neutralization test for typing, and to reverse transcription - polymerase chain reaction (RT-PCR) for detection of enteroviral RNA. It was found that 36 out of 100 placental tissue samples $(36 \%)$ were cell culture positive as they showed enterovirus - like cytopathic effect (CPE) in Vero cell culture, including 29/75 samples (38.7\%) from group A and 7/25 samples (28\%) from group $\mathrm{B}$, with statistically insignificant difference in results between both groups $(\mathrm{P}>0.05)$. All the 36 viral isolates of the cell culture positive samples were untypable by neutralization test with the available enteroviral antisera, while 26 of these isolates (72.2\%) were positive for enteroviral RNA by RT-PCR, comprising 21/29 isolates $(72.4 \%)$ from group A and $5 / 7$ isolates $(71.4 \%)$ from group B, with no statistically significant difference in results between both groups $(\mathrm{P}>0.05)$. The remaining 10 viral isolates were negative for enteroviral RNA by RT-PCR and were attributed to other CPE producing viruses which may induce miscarriage. As 26 out of 100 samples $(26 \%)$ were positive in both cell culture and RT-PCR, thus the obtained incidence of enteroviral infections among cases of miscarriage was $26 \%$. This incidence is considered to be a quite high one, needing further attention and studies. No relation was found between age or parity and enteroviral infections in the studied groups. Enteroviruses may be considered as important causative agents of miscarriage, and enteroviral infections should be investigated in all cases of miscarriage. Further studies including typing of enteroviral isolates from cases of miscarriage by sequencing are recommended.
\end{abstract}

\section{Introduction :}

Several viral diseases with a confirmed effect on the fetus and neonate have attracted particular attention. Maternal infection with rubella virus, cytomegalovirus, human immunodeficiency virus, parvovirus B19, hepatitis B virus, herpes simplex virus type 1 and 2 , varicella zoster virus and influenza virus have all shown to be linked to an

adverse outcome for the fetus and neonate (Carrington, 1990).

Enterovirus infections during pregnancy have been associated with a variety of fetal complications. Gestational poliovirus infection caused spontaneous abortion and stillbirths, especially with severe maternal disease (Palmer et al., 1997). Infection with

Referee : Prof ; Dr. Ragaa Abdallah Awad . 
non-poliovirus enteroviruses has been also linked to spontaneous abortion, stillbirths and fetal congenital anomalies, with enteroviruses detected in the amniotic fluid, placenta and fetal tissues by electron microscopy, culture, immunofluorescence and polymerase chain reaction (Palmer et al., 1997).

The aim of the present study was to determine the incidence of enteroviral infections in cases of miscarriage and to clarify the implication of these infections in these cases.

\section{Patients and Methods : \\ Subjects and samples :}

One hundred women with miscarriage were included in the present study. They were attending the Obstetric and Gynecology Departments of El Galaa Teaching Hospital, Qwesna District Hospital or Al-Zahraa University Hospital. They were grouped into 2 groups : A and B. Group A included 75 women having miscarriage before the $13^{\text {th }}$ week of gestation, and comprising 12 primigravida and 63 multigravida cases, with an age range from 18 to 39 years (mean age $27 \pm 5.01$ years). While group B included 25 women having miscarriage after the $13^{\text {th }}$ week of gestation, and comprising 5 primigravida and 20 multigravida cases, with an age range from 19 to 40 years (mean age $30.2 \pm 5.76$ years).

Placental tissue samples were taken from all women (one sample from each woman). All samples were collected in sterile containers, transported to the laboratory in an ice box and stored at $-70^{\circ} \mathrm{C}$ until the time of processing.

\section{Processing of samples for virus isolation :}

Placental tissue samples were washed separately and repeatedly with phosphate buffered saline (PBS) solution until the solution became clear. Then
$1 \mathrm{ml}$ of $5 \mathrm{X}$ antibiotic solution [formed of 5000000 units of penicillin $\mathrm{G}$ sodium, 25 grams of streptomycin sulfate and $5 \mathrm{mg}$ of fungizone in $100 \mathrm{ml}$ of Hank's balanced salt solution (HBSS)] was added to each sample which was then cut into very small pieces, suspended in $4 \mathrm{ml}$ of Hank's balanced salt solution, mixed thoroughly and centrifuged at 1000 r.p.m. for 10 minutes. The supernatant was collected and stored in aliquots at $-70^{\circ} \mathrm{C}$ till the time of inoculation into cell culture.

\section{Isolation of enteroviruses in cell culture :}

Processed samples were inoculated each in $0.1 \mathrm{ml}$ volume into two Vero cell culture tubes with confluent monolayers. The tubes were incubated at $37^{\circ} \mathrm{C}$ for $2-3$ hours to allow virus adsorption, then $1 \mathrm{ml}$ of maintenance medium [Eagle's minimum essential medium (EMEM) containing $2 \%$ fetal calf serum (FCS)] was added, followed by further incubation at $37^{\circ} \mathrm{C}$ and daily microscopic observation for the presence of viral cytopathic effect (CPE) for the next 15 days using an inverted microscope. Four uninoculated Vero cell culture tubes were also included as cell culture controls. Cultures were considered positive when the characteristic enterovirus CPE, consisting of cell rounding and shrinking, nuclear pyknosis, and cell degeneration, were observed. When CPE reached third degree $(+3)$, the cell culture tubes were freezed and thawed for three times to release cell associated virus into the suspension. The cellular debris in the suspension were then precipitated by centrifugation at 3000 r.p.m. at $4^{\circ} \mathrm{C}$ for 15 minutes. The supernatant was then collected, diluted $\frac{1}{1000}$ and subjected to another two successive passages in cell culture. The harvest of the third 
passage was divided into aliquots and stored at $-70^{\circ} \mathrm{C}$ to be used in neutralization test and reverse transcription - polymerase chain reaction (RTPCR). Negative cultures gave no CPE during the 15 days follow up period.

\section{Neutralization test for typing of the viral isolates (the viral harvests) :}

It was carried out on the viral harvests of the third passage of cell culture positive samples using reference antisera to enteroviruses [American Type Culture Collection (ATCC)]. Three different pools were prepared fro$m$ the available antisera by mixing equal volumes of the included antisera and then diluting each pool $1: 10$ in sterile distilled water. These pools were :

Pool CA: containing antisera to Coxsackievirus A type A3, A4, A5, A6 and A9.

Pool CB: containing antisera to Coxsackievirus B type B2, B3, B4, B5 and B6.

Pool E: containing antisera to Echovirus type 5 and 9.

Serial doubling dilution of each viral isolate (viral harvest) in HBSS was done and equal volumes $(50 \mu \mathrm{l})$ of each virus dilution and each enterovirus antisera pool were incubated at $4^{\circ} \mathrm{C}$ for 24 hours. Then each virus - antisera mixture was inoculated in 2 wells in a volume of $50 \mu \mathrm{l}$ per well in 96 wells tissue culture plates (Falcon, Becton Dickinson, Lipincom Park, New Jersy, U.S.A.) containing Vero cell monolayers. Each virus dilution alone was inoculated in one well as a virus control, and uninoculated cell culture wells were used as cell controls. Plates were incubated at $37^{\circ} \mathrm{C}$ and examined daily by an inverted microscope.

Detection of enteroviral RNA by RTPCR :

It was carried out on the viral harvests of the third passage of cell culture positive samples. RNA extraction was performed according to Kaucner and Stinear (1998) by adding 4 $\mu \mathrm{l}$ of $5 \mathrm{X}$ RT buffer (Promega, Madison, U.S.A.) to $5 \mu \mathrm{l}$ of each viral isolate (viral harvest) and then covering the mixture with $50 \mu \mathrm{l}$ of mineral oil (Sigma, U.S.A). The mixture was exposed to heat shock by heating at $99^{\circ} \mathrm{C}$ for 5 minutes then chilling on ice. One $\mu$ l of 40 U RNase inhibitor (Promega) was then added.

Reverse transcription was performed in $20 \mu \mathrm{l}$ volume containing $10 \mu \mathrm{l}$ of extracted RNA, $1 \mu$ containing 5 $\mathrm{mM}$ of each of deoxyribonucleoside triphosphates (dNTPs) (Promega), $1 \mu \mathrm{l}$ containing $0.25 \mu \mathrm{M}$ of antisense primer and $1 \mu \mathrm{l}(200 \mathrm{U})$ of Moloney murine leukemia virus - reverse transcriptase (MMLV-RT) (Promega), and $7 \mu \mathrm{l}$ of diethyl pirocarbonate (DEPC) - treated water. The mixture was subjected to the following temperature conditions : $25^{\circ} \mathrm{C}$ for 10 minutes, $42^{\circ} \mathrm{C}$ for 30 minutes, $99^{\circ} \mathrm{C}$ for 5 minutes and $4^{\circ} \mathrm{C}$ for 10 minutes; and the produced cDNA was used in PCR (Kaucner and Stinear, 1998).

PCR amplification was accomplished by the addition of a mixture containing $8 \mu \mathrm{l}$ of $10 \mathrm{X}$ PCR buffer (Promega), $2 \mu \mathrm{l}$ of $10 \mathrm{mM}$ d NTPs, $2 \mu \mathrm{l}$ of each of sense and antisense primers (Research Genetics, U.K.), $1 \mu \mathrm{l}$ (5 U) of Taq DNA polymerase (Sigma) and 45 $\mu l$ of DEPC - treated water to $20 \mu l$ of the cDNA to a final volume of $80 \mu$ l.

The primers used were derived from the highly conserved sequence in the 5' non translated region (5' NTR) of the enterovirus genome according to Chapman et al. (1990). These primers were the sense primer $\mathrm{E}_{2}$ (5'-TCCGG CCCCTGAATG-3', nt 445 to 460) and the antisense primer E1 (5'-ACACG GACCCAAAGT-3', nt 595 to 578). 
They are universal primers for enteroviruses.

Amplification was carried out in a thermal cycler for 40 cycles of denaturation at $95^{\circ} \mathrm{C}$ for 1 minute, annealing at $55^{\circ} \mathrm{C}$ for 1 minute and extension at $72^{\circ} \mathrm{C}$ for 1 minute, followed by a final extension at $72^{\circ} \mathrm{C}$ for 10 minutes as an elongation step (Martin et al., 1994).

With each PCR run, a negative control (containing PCR buffer only) and a positive control (containing enterovirus strain) were included.

Detection of the amplification products was done by carrying out gel electrophoresis on a $2 \%$ agarose gel, staining with ethidium bromide and visualization under ultraviolet (U.V.) light. Enteroviral RNA - positive isolates were determined by the presence of 151 base pair (151 bp) fragments coinciding with the positive control.

\section{Statistical analysis :}

Chi square test was used to analyze the obtained results.

\section{Results :}

\section{I- Virus isolation in cell culture :}

Thirty - six out of 100 placental tissue samples $(36 \%)$ were cell culture positive as they showed enterovirus like CPE in Vero cell culture (Photo 1). They included 29/75 samples (38.7\%) from group A and 7/25 samples (28\%) from group B. Difference in results between group A and group B was statistically insignificant $(\mathrm{P}>0.05)$ (Table 1 and Figure 1).

Table 1 : Virus isolation from placental tissue samples in Vero cell culture

\begin{tabular}{|l|l|l|l|l||}
\hline Group & $\begin{array}{l}\text { Number of } \\
\text { samples }\end{array}$ & $\begin{array}{c}\text { Number of cell culture } \\
\text { positive samples } \\
\text { (percentage) }\end{array}$ & $\begin{array}{c}\text { Number of cell culture } \\
\text { negative samples } \\
\text { (percentage) }\end{array}$ & P value \\
\hline \hline A & 75 & $29(38.7 \%)$ & $46(61.3 \%)$ & P>0.05 \\
B & 25 & $7(28 \%)$ & $18(72 \%)$ & non significant \\
\hline \hline Total & 100 & $36(36 \%)$ & $64(64 \%)$ & \\
\hline
\end{tabular}

* All the viral isolates of the cell culture positive samples were found to be untypable with the available enteroviral antisera in neutralization test.

Figure 1 : Cell culture positive and negative samples in group A and group B.

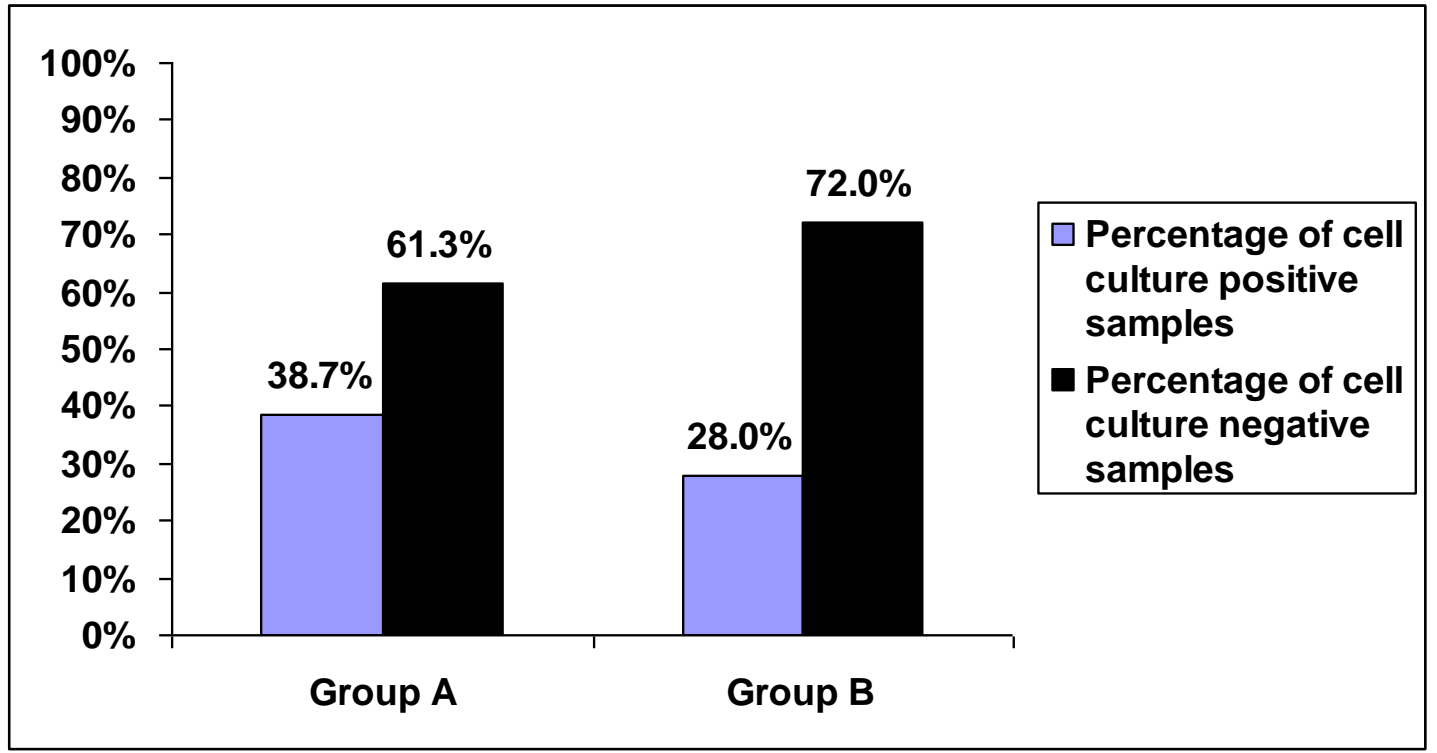


II- Neutralization test for typing of the viral isolates :

All the 36 viral isolates of the 36 cell culture positive samples were found to be untypable in neutralization test with the available enteroviral antisera (Table 1).

\section{III- Detection of enteroviral RNA} in the viral isolates of cell culture positive samples by RT-PCR :
Twenty-six out of the 36 viral isolates $(72.2 \%)$ were found to be positive for enteroviral RNA by RTPCR, so they were RT-PCR positive. They included $21 / 29$ isolates $(72.4 \%)$ from group A and 5/7 isolates (71.4\%) from group B. Difference in results between both groups was statistically insignificant $(\mathrm{P}>0.05)$ (Table 2, Figure 2 and Photo 2).

Table 2 : Enterovirus RNA detection by RT-PCR in the viral isolates of cell culture positive samples in the studied groups.

\begin{tabular}{|c|c|c|c|c|}
\hline Group & $\begin{array}{c}\text { Number of } \\
\text { viral } \\
\text { isolates }\end{array}$ & $\begin{array}{c}\text { Number of enterovirus } \\
\text { RNA positive viral } \\
\text { isolates (percentage) }\end{array}$ & $\begin{array}{c}\text { Number of enterovirus } \\
\text { RNA negative viral } \\
\text { isolates (percentage) }\end{array}$ & P value \\
\hline \hline A & 29 & $21(72.4 \%)$ & $8(27.6 \%)$ & $\begin{array}{c}\text { P }>0.05 \\
\text { non significant }\end{array}$ \\
\hline B & 7 & $5(71.4 \%)$ & $2(28.6 \%)$ & \\
\hline Total & 36 & $26(72.2 \%)$ & $10(27.8 \%)$ & \\
\hline
\end{tabular}

Figure 2 : RT-PCR results in the viral isolates of cell culture positive samples in the studied groups.

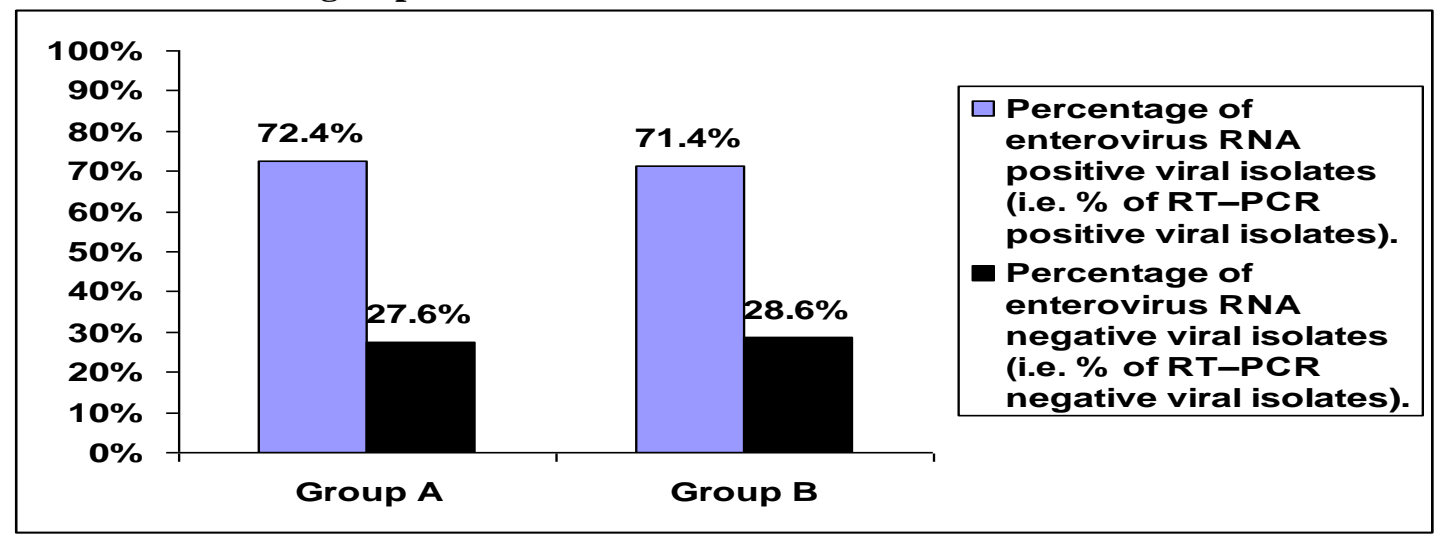

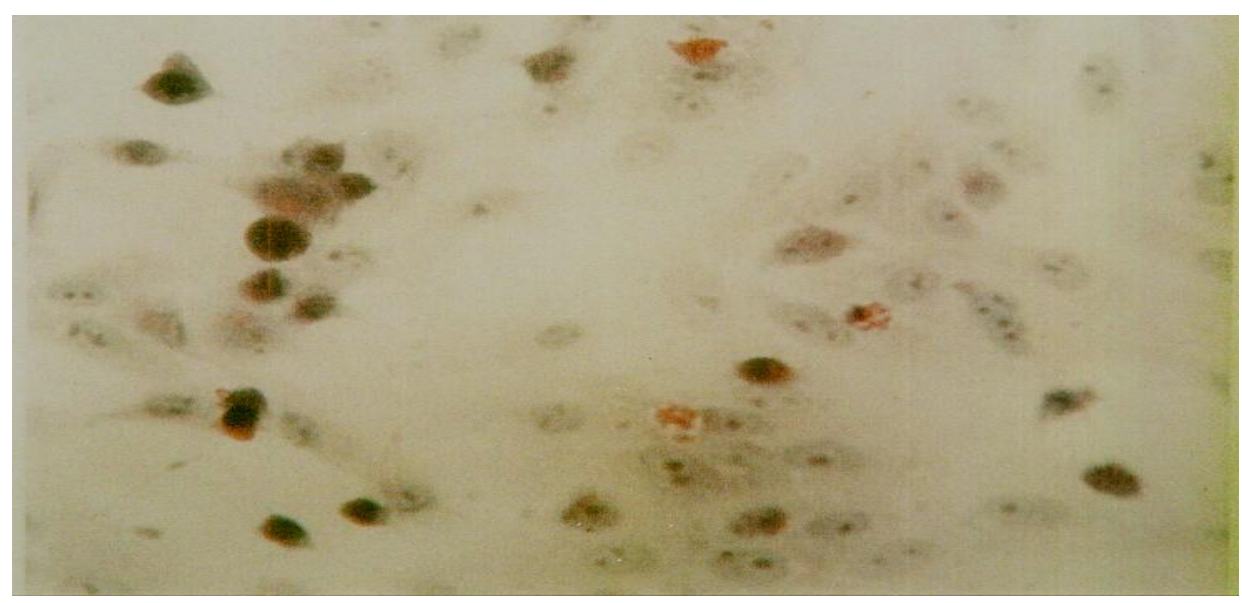

Photo 1 : Enterovirus - like CPE in Vero cell culture inoculated with placental tissue samples. 


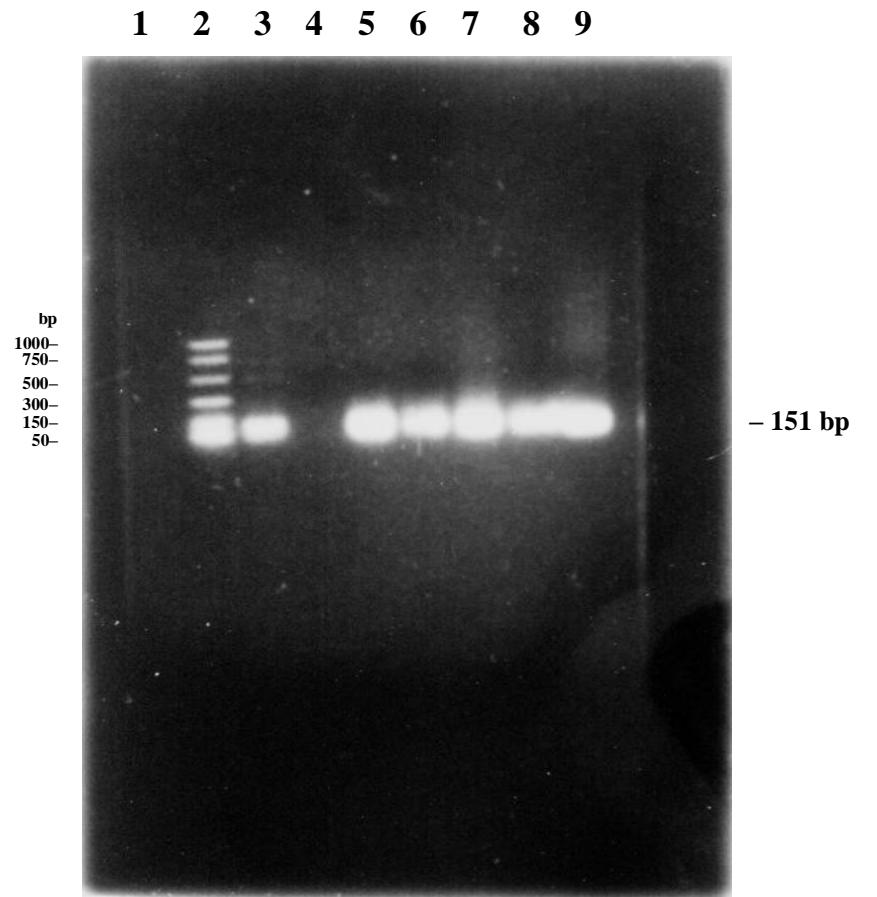

Photo 2 : Detection of enteroviral RNA in the viral isolates by RT-PCR.

Lane 1 : negative control.

Lane 2 : PCR marker (molecular weight marker).

Lane 3 : positive control.

Lane 4 : negative sample.

Lane 5, 6, 7, 8, 9 : positive samples with specific bands of 151 base pair (151 bp) coinciding with the positive control.

Enteroviral infections were excluded from the 10 cell culture positive samples whose viral isolates were negative for enteroviral RNA by RT-PCR. On the other hand, enteroviral infections were confirmed in the remaining 26 cell culture positive samples, as the viral isolates of these samples were positive for enteroviral RNA by RT-PCR. Thus 26 out of 100 women with miscarriage $(26 \%)$ had enteroviral infections, 21 of them were from group A and 5 of them were from group B. No statistically significant difference in results was found between both groups $(\mathrm{P}>0.05)$ (Table 3$)$.

Table 3 : Enteroviral infections in cases of miscarriage.

\begin{tabular}{||c|c|c|c|c||}
\hline \hline Group & $\begin{array}{c}\text { Number of } \\
\text { cases }\end{array}$ & $\begin{array}{c}\text { Number of positive } \\
\text { cases for enteroviral } \\
\text { infections (percentage) }\end{array}$ & $\begin{array}{c}\text { Number of negative } \\
\text { cases for enteroviral } \\
\text { infections (percentage) }\end{array}$ & P value \\
\hline \hline A & 75 & $21(28 \%)$ & $54(72 \%)$ & $\begin{array}{c}\text { P>0.05 } \\
\text { non significant }\end{array}$ \\
\hline \hline B & 25 & $5(20 \%)$ & $20(80 \%)$ & $74(74 \%)$ \\
\hline
\end{tabular}

Relating between age or parity and enteroviral infections, it was found that in group A, enterovirus - infected cases had a mean age of $26.7 \pm 5.19$ years, while non infected cases had a mean age of $27.1 \pm 4.98$ years. In group B, enterovirus - infected cases had a mean age of $27.6 \pm 6.23$ years, while non infected cases had a mean age of $30.8 \pm$ 5.62. No statistically significant difference in age was found between enterovirus - infected and enterovirus uninfected cases in both groups $(\mathrm{P}>0.05)$, and no relation was found 
between age and enteroviral infections in the studied groups (Table 4).

As regard parity, it was found that 4 primigravida cases ( 3 cases from group A and one case from group B) had enteroviral infections, while 13 primigravida cases (9 cases from group A and 4 cases from group B) didn't have enteroviral infections. In addition, 22 multigravida cases (18 cases from group $A$ and 4 cases from group B) were infected by enteroviruses, while 61 multigravida cases (45 cases from group A and 16 cases from group B) were not infected by enteroviruses. No statistically significant difference in parity (whether primigravida or multigravida) was found between enterovirus infected and enterovirus - uninfected cases in both groups $(\mathrm{P}>0.05)$ and no relation was found between parity and enteroviral infections in the studied groups (Table 4).

Table 4 : Relation between age or parity and enteroviral infections.

\begin{tabular}{|c|c|c|c|c|c|}
\hline \multirow[b]{2}{*}{ Item } & \multicolumn{2}{|l|}{ Group A } & \multicolumn{2}{|l|}{ Group B } & \multirow[b]{2}{*}{$P$ value } \\
\hline & $\begin{array}{l}+\mathrm{ve}^{*} \\
(\mathrm{n}=21)\end{array}$ & $\begin{array}{l}-\mathrm{ve} \\
(\mathrm{n}=54)\end{array}$ & $\begin{array}{l}+v^{*} \\
(n=5)\end{array}$ & $\begin{array}{l}-\mathrm{ve} \\
(\mathrm{n}=20)\end{array}$ & \\
\hline $\begin{array}{l}\text { Age } \\
\text { Mean } \pm \text { S.D. } \\
(\text { range in years) }\end{array}$ & $\begin{array}{l}26.7 \pm 5.19 \\
(18-35)\end{array}$ & $\begin{array}{l}27.1 \pm 4.98 \\
(20-39)\end{array}$ & $\begin{array}{l}27.6 \pm 6.23 \\
(20-37)\end{array}$ & $\begin{array}{l}30.8 \pm 5.62 \\
(19-40)\end{array}$ & $\begin{array}{l}\mathrm{P}>0.05 \\
\text { non significant }\end{array}$ \\
\hline $\begin{array}{l}\text { Parity: } \\
\text { - Primigravida } \\
\text { [number of +ve or } \\
\text {-ve / total } \\
\text { (percentage)] } \\
\text { - Multigravida } \\
\text { [number of +ve or } \\
\text {-ve / total } \\
\text { (percentage)] }\end{array}$ & $\begin{array}{l}3 / 21(14.3 \%) \\
18 / 21(85.7 \%)\end{array}$ & $9 / 54(16.7 \%)$ & $1 / 5(20 \%)$ & $4 / 20(20 \%)$ & $\begin{array}{l}\mathrm{P}>0.05 \\
\text { non significant }\end{array}$ \\
\hline
\end{tabular}

* +ve : positive for enteroviral infections.

- $\quad-$ ve : negative for enteroviral infections.

- S.D. : standard deviation.

\section{Discussion :}

Viral infections during pregnancy may pose significant problems to the patient, her fetus and her attendants. Maternal - fetal transmission of enteroviruses can induce spontaneous abortion and stillbirths (Carrington, 1990; Abzug, 1997; Patural et al., 1999). In this concern, poliovirus infection during pregnancy has been found to cause spontaneous abortion and stillbirths, especially with severe maternal disease. Polioviruses were detected by immunofluorescence in the myocardia of stillbi- rths (Abzug et al., 1991; Palmer et al., 1997).

Gestational infections with non poliovirus enteroviruses have been associated with spontaneous abortion, stillbirths and fetal congenital anomalies, with enteroviruses detected in the placenta, amniotic fluid and fetal tissues by electron microscopy, culture, immunofluorescence and polymerase chain reaction (Palmer et al., 1997). Coxsackie B viruses are capable of crossing the placental barrier, infecting 
the fetus and causing fetal malformation (Carrington, 1990).

The present study was carried out on placental tissue samples from 100 women with miscarriage, 75 of whom (group A) had miscarriage before the $13^{\text {th }}$ week of gestation, while the remaining 25 (group B) had miscarriage after the $13^{\text {th }}$ week of gestation; and it was found that 36 out of 100 placental tissue samples (36\%) showed enterovirus - like CPE in Vero cell culture, including 29/75 samples (38.7\%) from group A and $7 / 25$ samples (28\%) from group B with statistically insignificant difference in results between both groups $(\mathrm{P}>0.05)$.

In a previous study, El Esnawy et al. (2001) also succeeded in isolation of enteroviruses from placental tissue samples from cases of miscarriage by cell culture, as they found that 2 out of 12 placental tissue samples (16.7\%) from cases of miscarriage in the last trimester showed enterovirus - like CPE in cell culture.

Similarly, enterovirus isolation from placental tissue samples from cases of miscarriage by cell culture done in the present study comes in agreement with the study done by Axelsson et al. (1993) who isolated an enterovirus which was coxsackie B virus from the placental tissues of 6 out of 23 $(26.1 \%)$ women with miscarriage before the $13^{\text {th }}$ week of gestation. But in contrary to the present study, they could not isolate the virus from the five placental tissue samples taken from women with miscarriage after the $13^{\text {th }}$ week of gestation. This disagreement may be due to the small number of samples they used for virus isolation.

Earlier studies also isolated different enteroviruses from placental tissues as well as fetal tissues in pregnancies ended with miscarriage (Basso et al., 1990; Garcia et al., 1990).
Enteroviruses were also isolated from different maternal and fetal specimens in these pregnancies with adverse outcomes (Johansson et al., 1992; Strong and Young, 1995; Chow et al., 2000).

On the other hand; Amstey et al. (1988) reported the case of 14 pregnant women, including 4 with meningitis, who despite having enterovirus infection from the $16^{\text {th }}$ to the $37^{\text {th }}$ week of gestation, yet they delivered uninfected healthy infants, and no enteroviruses were isolated from the placental tissues.

In the present study, the viral isolates were found to be untypable in neutralization test with the available enteroviral antisera. This may be attributed to the possibility that the pools of antisera we used were not specific for the viral isolates. In addition, the neutralization test may fail, and untypable enteroviruses may still be encountered (Manayani et al., 2002). Neutralization test may fail to resolve the serotype when there is aggregation of enterovirus strains, antigenic variations, or multiple serotypes of enteroviruses in the specimen. Adding to the problem, the fact that antisera used for neutralization of enterovirus isolates are not commercially available and the supply from the World Health Organization (WHO) is now becoming very limited (Pallansch and Roos, 2001).

In contrary, El Esnawy et al. (2001), by using dot-ELISA, typed 12 enterovirus isolates from aborted women's sera and 11 enterovirus isolates from aborted tissues; while 2 isolates were untypable.

In the present study, RT-PCR was carried out on the viral isolates to confirm the presence of enteroviruses by detection of the enteroviral RNA in these viral isolates, and it was found that 26 out of the 36 viral isolates $(72.2 \%)$ were positive for enteroviral 
RNA, including 21 out of 29 isolates (72.4\%) from group A and 5 out of 7 isolates $(71.4 \%)$ from group $\mathrm{B}$, with statistically insignificant difference in results of RT-PCR between both groups $(\mathrm{P}>0.05)$. The 10 viral isolates which were negative for enteroviral RNA and were untypable by neutralization test may be attributed to other CPE producing viruses that may induce miscarriage.

The present study is in agreement with the study performed by Johansson et al. (1992) who detected enteroviral RNA in the placenta of a fetus with an intrauterine fetal death at the $29^{\text {th }}$ week of gestation. They also detected this nucleic acid in the myocardium, liver and lung of the fetus. While Chow et al. (2000) detected enterovirus 71 RNA in the cord blood of a stillborn baby at the $26^{\text {th }}$ week of gestation. In addition, El Esnawy et al. (2001) detected enteroviral RNA in 2 out of $2(100 \%)$ placental tissue samples from women with miscarriage in the last trimester of pregnancy. They also detected this RNA in 11 out of $13(84.6 \%)$ aborted tissue samples and in 12 out of $12(100 \%)$ aborted women's serum samples that induced CPE in cell culture.

In the present study, 26 out of 100 samples $(26 \%)$ were positive in both cell culture and RT-PCR, thus the obtained incidence of enteroviral infections among cases of miscarriage was $26 \%$. This incidence is considered to be a quite high one, directing the attention towards enteroviral infections and their dangerous effects on pregnancy, causing miscarriage and adverse outcomes. It is consistent with the incidence obtained by Axelsson et al. (1993) who reported an incidence of enteroviral infections of $26.1 \%$ among cases of miscarriage. On the other hand, it is higher than the incidence of $16.7 \%$ obtained by El Esnawy et al. (2001).
Finally, no relation was found, in our study, between age or parity and enteroviral infections in the studied groups.

In conclusion, 36 out of 100 (36\%) placental tissue samples from cases of miscarriage showed enterovirus - like CPE in Vero cell culture, including 29/75 samples from cases with miscarriage before the $13^{\text {th }}$ week of gestation (group A) and 7/25 samples from cases with miscarriage after the $13^{\text {th }}$ week of gestation (group B). All the 36 viral isolates of the cell culture positive samples were untypable by neutralization test with the available enteroviral antisera, while 26 of these isolates were positive for enteroviral RNA by RT-PCR, including 21 isolates from group $\mathrm{A}$ and 5 isolates from group B. No statistically significant difference in results was obtained between both groups $(\mathrm{P}>0.05)$. An incidence of enteroviral infections in cases of miscarriage of $26 \%$ was obtained, and no relation was found between age or parity and enteroviral infections in the studied groups. The results of this study point to the potential danger of enteroviral infections during pregnancy and the necessity to evaluate enteroviral infections in pregnant women. Enteroviruses may be considered as important causative agents of miscarriage, and enteroviral infections should be investigated in all cases of miscarriage. Further studies including typing of enterovirus isolates by sequencing are recommended.

\section{Acknowledgements :}

We would like to express our thanks to members of Obstetric and Gynecology Departments of El Galaa Teaching Hospital, Qwesna District Hospital and Al-Zahraa University Hospital for their help in collection of samples. We would like also to thank Dr. M. A. Ali at National Research Centre for his help in RT-PCR. 


\section{References :}

1. Abzug M.J. (1997). Maternal factors affecting the integrity of the late gestation placental barrier to murine enterovirus infection. J. Infect. Dis.; 176 (1) : 41-49.

2. Abzug M.J., Rotbart H.A., Maglito S.A. and Levin M.J. (1991). Evolution of the placental barrier to fetal infection by murine enteroviruses. J. Infect. Dis.; 163 : 1336-1341.

3. Amstey M.S., Miller R.K., Menegus M.A. and Disant P.A. (1988). Enterovirus in pregnant women and the perfused placenta. Am. J. Obstet. Gynecol.; 158 : 775-782.

4. Axelsson C., Bondestan K., Frisk G., Bergstrom $S$. and Diderholm $H$. (1993). Coxsackie B virus infections in women with miscarriage. J. Med. Virol.; 39 : 282-285.

5. Basso N.G., Fonseca M.E., Garcia A.G., Zuardi J.A., Silva M.A. and Outani H. (1990). Enterovirus isolation from fetal and placental tissues. Acta Virol.; 34 (1): 49-57.

6. Carrington D. (1990). Viral infection during pregnancy. In : Maclean A.B. (ed). Clinical Infection in Obstetric and Gynecology. Black Well Scientific Publications, Oxford, p. 39-71.

7. Chapman N.M., Tracy S., Gauntt C.J. and Fortmueller U. (1990). Molecular detection and identification of enteroviruses using enzymatic amplification and nucleic acid hybridization.

J. Clin. Microbiol.; 28: 843-850.

8. Chow K.C., Lee C.C., Lin T.Y., Shen W.C., WangJ.H., Peng C.T. and Lee C.C. (2000). Congenital enterovirus 71 infection : a case study with virology and immunohistochemistry. Clin. Infect. Dis.; 31: 509-512.

9. El Esnawy N.A., Ali M.A., Bayoumi F.S., Abo El Khir A. and Abdel Wahab K.S.E. (2001). Waterborne viruses associated with repeated abortion. The Journal of the Egyptian Public Health Association, 27(5): 487-503.

10. Garcia A.G., Basso N.G., Fonseca M.E. and Outani H.N. (1990). Congenital echovirus infection : morph- ological and virological study of fetal and placental tissue. J. Pathol.; 160: 123-127.

11. Johansson M.E.,HolmstromS., Abebe A.,Jacobsson B.,Ekman G., SamueIson A. and Wirgart B.Z. (1992). Intrauterine fetal death due to echovirus 11. Scand. J. Infect. Dis.; 24: 381-385.

12. Kaucner C. and Stinear T. (1998). Sensitive and rapid detection of viable Giardia cysts and Cryptospondium Parvum oocysts in large volume of water samples with wound fiberglass cartridge filters and reverse transcriptase polymerase chain reaction. Appl. Environ. Microbiol.; 64 (5):1743-1749.

13. Manayani D.J., Shaji R.V., Fletcher G.J., Cherian T., Murali N., Sathish N., Solomon T., Gnanamuthu C. and Sridharan G. (2002). Comparison of molecular and conventional methods for typing of enteroviral isolates. J. Clin. Microbiol.; 40 (3): 1069-1070.

14. Martin A.B., Webber S., Fricker F.J., Jaffe R., Demmler G., Kearney D., Zhang Y.H., Bodurtha J., Gelb B. and Ni J. (1994). Acute myocarditis. Rapid diagnosis by PCR in children. Circulation; 90 (1): 330-339.

15. Pallansch M.A. and Roos R.P. (2001). Enteroviruses : Polioviruses, Coxsackieviruses, Echoviruses and Newer Enteroviruses. In : Fields B.N., Knipe D.M., Howley P.M., Jriffine D.E., Martin M.A., Lamb R.A., Roisizeman B. and Straus S.E. (eds). Fields Virology, $4^{\text {th }}$ edition, volume 2, Lippincott Williams and Wilkins, Philadelphia, p. 723-775.

16. Palmer A.L., Rotbart H.A., Tyson R.W. and Abzug M.J. (1997). Adverse effects of maternal enterovirus infection on the fetus and placenta. J. Infect. Dis.; 176: 1437-1444.

17. Patural H., Teyssier G. and Pozzeto B. (1999). Enterovirus infections in children under three months of age. Arch. Pediatr.; 6 (11): 1205-1211.

18. Strong B.S. and Young S.A. (1995). Intrauterine coxsackievirus group B type 1 infection : viral cultivation from amniotic fluid in the third trimester. Am. J. Perinatol.; 12 (2): 78-79. 


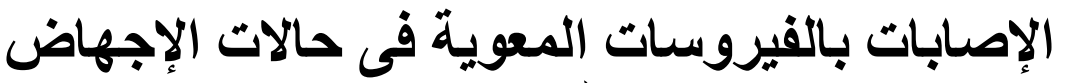

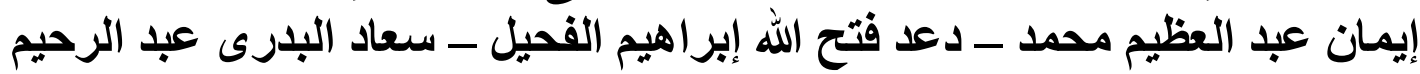

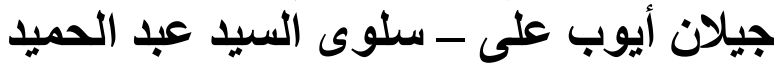 \\ قسم الميكروبيولوجى - كلية طب بنات البن - جامعة الأز هر}

شمل البحث مائة مريضة يعانين من حالات إجهاض، وقد تم تقسيم المريضات إلى بحموعتين : بجموعة (أ) وتشمل

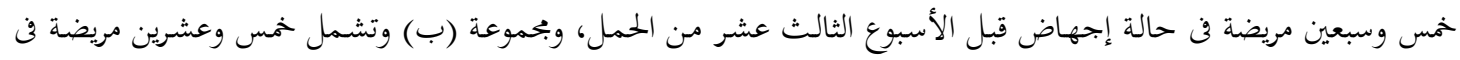

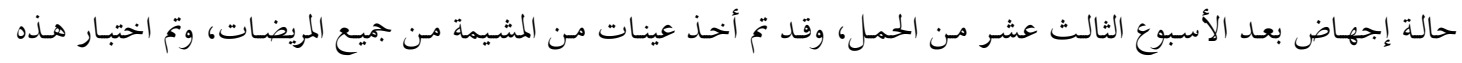

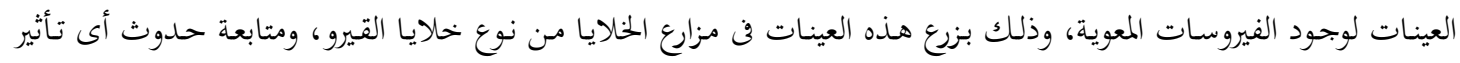

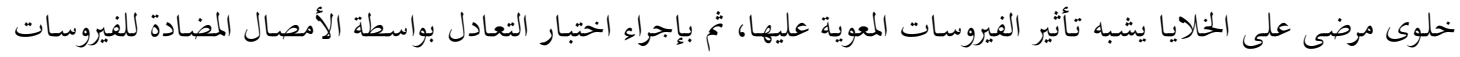

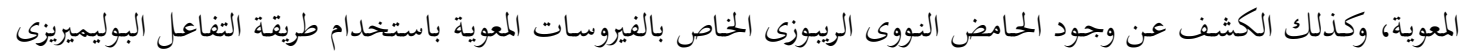
المتسلسل على الفيروسات المعزولة من العينات ذات التأثير الخلوى المرضى المشابه لتأثير الفيروسات المعوية.

\section{وقد خلص البحث إلى النتائج التالية :}

- إن ست وثلاثين عينة من المشيمة (بنسبة 36\%) قد أعطت نتائج إيجابية في مزارع الخلايا، حيث أها أحدثت تأثير خلوى

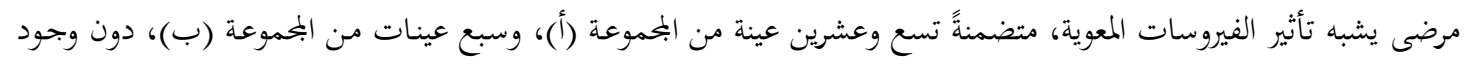
أى فرق ذى مغزى أو دلالة إحصائية بين المجموعتين.

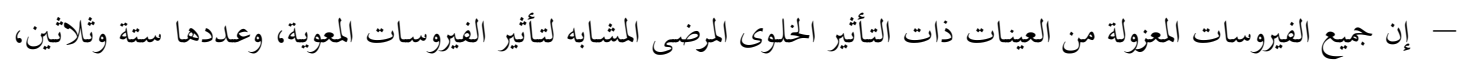
لم يمكن تصنيفها باستخدام اختبار التعادل بواسطة الأمصال المتاحة والمضادة للفيروسات المعوية.

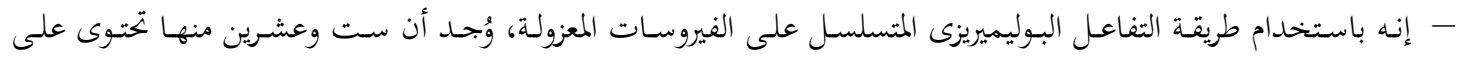

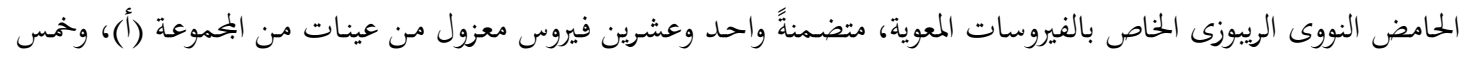

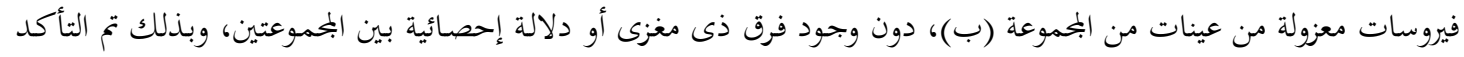
من وجود الإصابات بالفيروسات المعوية في هذه العينات الست والعشرين، بينما تم استبعاد وجود الإصابات بالفيروسات المعوية في العشر عينات الباقية لعدم وجود الحامض النووى الريبوزى الخاص بالفيروسات المعوية فن هذه العينات، مع إمكانية احتوائها

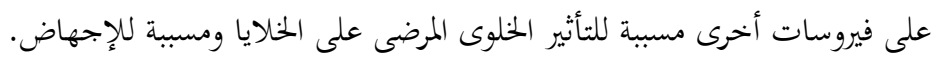

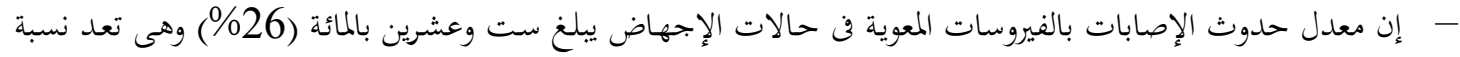
عالية تستوجب الاهتمام والمزيد من الدراسات. - إنه لا يوجد علاقة بين العمر أو الإنحابية ووجود الإصابات بالفيروسات المات المعبوية في المحموعتين اللتين كانتا تحت الدراسة.

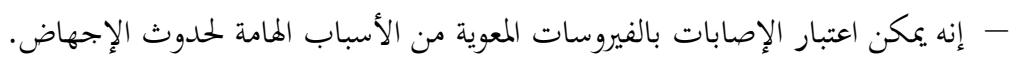
- إنه يُوصى بإجراء اختبارات الكشف عن وجود الفيروسات المعوية عند فحص حالات الإجهاض.

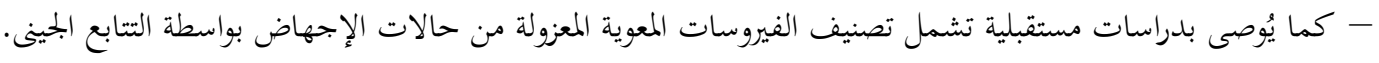

